\title{
Chapter 2 \\ The Autonomy of EU Law: More is Less?
}

\author{
Jan Willem van Rossem
}

\begin{abstract}
Sixty years after its launch by the European Court of Justice in the case of Costa v ENEL, the notion that EU law derives from an autonomous source still leads to divergent interpretations. In this chapter, it is submitted that the concept of EU autonomy in effect comes down to a disguised claim to sovereignty. Contrary to what is often believed, such a reading, which is premised on the Court's insistence on the self-referential nature of the Union legal order, provides a promising point of departure for assessing the manner in which the EU deals and, in the future, should deal with norms that originate in international law. In particular, perceiving the claim to authority in Costa $v$ ENEL and more recent cases such as Kadi as a claim to sovereignty could pave the way for a jurisprudential approach in which deference towards international law is the norm and in which resistance towards external norms is only acceptable if such norms put the constitutional identity of the EU at risk. More autonomy vis-à-vis international law might actually mean less autonomy.
\end{abstract}

\section{Contents}

2.1 Introduction

2.2 Autonomy as a Foundational Concept ................................................................ 15

2.3 Autonomy as a Precondition for Unity

Many thanks to Christina Eckes for her valuable comments on an earlier version of this chapter.

J. W. van Rossem ( $\square)$

Department of Constitutional Law and Administrative Law,

Utrecht University, Utrecht, The Netherlands

e-mail: j.w.c.vanrossem@uu.nl

R. A. Wessel and S. Blockmans (eds.), Between Autonomy and Dependence, 
2.4 Verfassungsverbund, Self-Contained Regime or Sovereignty in Disguise? 22

2.5 Freedom That is Organised by International Law and Committed to it............ 27

2.6 Boundaries

2.6.1 EU Law v UN Law: Kadi and Fundamental Rights....................................... 32

2.6.2 EU Law v Non-Binding International Agreements: Intertanko and Air Transport Association of America ..................................... 34

2.6.3 EU Law v Binding International Agreements: Mox Plant and UNCLOS ......... 38 2.7 Conclusion

\subsection{Introduction}

The central theme of this volume is the question whether the European Union (EU) can still be seen as an autonomous legal order. To be able to answer this question, one first needs to ascertain what autonomy means in the context of EU law. As it turns out, this is not an easy thing to do. The notion of the autonomy of EU law is something of an enigma, which, despite a recent surge in academic interest as a result of the decision by the European Court of Justice (ECJ) in the Kadi case, ${ }^{1}$ has always received relatively little attention, at least not in a conceptual manner. ${ }^{2}$ Does autonomy for example still have any real explanatory value with regard to Union law? If so, should we see this as proof of the fact that the EU has evolved into a "municipal" legal order or is it also possible to construe the notion in internationalist terms? After Kadi, it has become increasingly common among EU lawyers to conceptualise autonomy in a strong constitutional sense. Unclear, however, is what exactly this entails for the relationship between EU law and the international legal order. In short, does a constitutional conception of autonomy warrant the Court to flex its muscles in border situations or is it rather the other way around and should such an understanding induce the ECJ to lower the EU's thresholds?

To answer these questions, this chapter will first try to distil from the ECJ's case law what kind of concept autonomy is, in particular how it relates to the EU qua polity (Sect. 2.2). Secondly, it will link this to the most important rationale behind the concept, the Court's concern for the unity of EU law (Sect. 2.3). On the basis of that analysis, our next step will be to look into the overall nature of the EU legal

\footnotetext{
${ }^{1}$ ECJ Joined Cases C-402/05 P and C-415/05 P Kadi and Al Barakaat International Foundation v Council and Commission [2008] ECR I-6351.

2 See e.g. Craig and De Búrca 2008, who, at 202-204, only pay attention to the principle of autonomy in a specific external sense. Even a constitutional textbook like Lenaerts and Van Nuffel 2005 does not mention the concept. Two important exceptions to this rule are Barents 2004, who devoted a monograph to the concept, and Walker 2003a, which contains several contributions on the related question of sovereignty. See also the debate between Schilling 1996 and Weiler and Haltern 1996. Of more recent date is Griller 2008; De Witte 2010; Govaere 2010; Lock 2011a.
} 
order (Sect. 2.4). This examination subsequently enables us to come to the heart of the matter; that is, how a particular conception of the notion of autonomy might influence or perhaps even should influence the way in which the Court deals with legal problems which arise at the outer border of the EU legal order (Sect. 2.5). Arguing that from a theoretical perspective it makes the most sense to opt for a flexible approach in this respect, finally we will examine to which extent the Court currently succeeds in employing such an approach (Sect. 2.6). In line with the subject of this book, the focus in this section will lie on norms that are generated by international organisations.

\subsection{Autonomy as a Foundational Concept}

As everyone who is familiar with EU law knows, the origins of the notion of autonomy lie in the seminal case of Costa $v E N E L$, a decision which was handed down in 1964, eight years after the founding of the European Economic Community (EEC). ${ }^{3}$ In Costa, the Court finished a job that it had started one year earlier in Van Gend \& Loos, when it had proclaimed that primary law could, in case the judges in Luxembourg deemed this to be appropriate, have direct effect in the legal orders of the Member States. ${ }^{4}$ Direct effect, the ECJ reasoned, meant little if national norms could later set aside integrated European law, as the Italian Constitutional Court had earlier declared. Therefore, also a rule that ensured the primacy of European law over national law was needed. It is at this point that the concept of autonomy comes in. According to the ECJ, this rule could only be meaningfully established if one departed from the premise that Community law arose out of "an independent source of law", or, in the original French version, "une source autonome". Without such a basis, the Court felt, the primacy rule could fall prey to considerations of a national constitutional nature and that, in turn, would endanger the common market, which for its efficacy depends on the uniform application of European law in the Member States.

After Costa, the concept of autonomy disappeared from the radar for a long time. ${ }^{5}$ Eventually, it re-emerged at the beginning of the 1990s, in Opinion 1/91. ${ }^{6}$

3 ECJ Case 6/64 Costa v ENEL [1964] ECR 585.
4 ECJ Case 26/62 Van Gend \& Loos v Nederlandse Administratie der Belastingen [1963] ECR 1. On the legal archaeology of European law and the interrelationship between Costa and Van Gend, see e.g. Poiares Maduro and Azoulai 2010; De Witte 2011. Cf. also Vauchez 2010.

5 As a denominator for the relationship between the Union and the Member States, the notion only resurfaced in ECJ Case 11/70 Internationale Handelsgesellschaft [1970] ECR 1125, in which the ECJ clarified that the primacy rule makes no exception for norms of a constitutional nature. Cf. further ECJ Case 327/84 Ekro v Produktschap voor Vee en Vlees [1984] ECR 107, para 11; ECJ Case C-287/98 Linster [2000] ECR I-6719, para 43, in which the Court stressed the importance of "an autonomous and uniform interpretation" of Community measures.

${ }^{6}$ ECJ Opinion 1/91 EEA Agreement [1991] ECR I-6079. 
This time, the focus was not on the internal relationship between the Community and its Member States, but on the external relationship of the Community with the international legal order. The question that the Court had to answer in Opinion 1/91 was whether the Council could bind the Community to an international treaty, the EEA Agreement, which purported to copy some aspects of the Community model on an international scale and created a tribunal to oversee this. Initially, the ECJ rejected this scheme. ${ }^{7}$ In particular, it objected to the jurisdiction of the tribunal envisaged by the draft treaty. The EEA Agreement being a mixed treaty, this tribunal would have the power to define who- the Community or the Member States-was the correct party to the agreement in a given case. This, according to the Court, was "likely adversely to affect the allocation of responsibilities defined in the Treaties and the autonomy of the Community legal order", and therefore the exclusive jurisdiction of the ECJ. ${ }^{8}$ Thus, it appeared that the European legal order possessed an inner core-in particular the EC's unique judicial structure-that, save for treaty amendment, could not be touched by international law.

Despite the Court's constitutional rhetoric, it was possible after Opinion 1/91 to think that the concept of autonomy only applied to a limited category of treaties which contained rules that were almost identical to Community provisions. ${ }^{9}$ In the Mox Plant decision of 2006, however, it turned out that this was not the case. ${ }^{10}$ The theme of this judgment was the same as in Opinion 1/91: concern for the erosion of the Court's exclusive power of judicial review as a result of competition by an international tribunal. Yet the context in which this concern emerged was wholly different in Mox Plant. The treaty at issue in this case, the United Nations Convention on the Law of the Sea (UNCLOS), constitutes a global multilateral agreement with a clear subject of its own: the law of the sea. Moreover, it had already been concluded by the Community (as a mixed agreement). This did not deter the ECJ, however, from invoking the notion of autonomy. Faced with the prospect of two Member States fighting outside its own courtroom over a legal question that, allegedly, touched upon EU law, it concluded that it could not accept the "manifest risk that the jurisdictional order laid down in the Treaties" would be affected. ${ }^{11}$

\footnotetext{
7 A revised draft EEA Agreement was held compatible with the Treaties by the ECJ in Opinion 1/92 EEA Agreement II [1992] ECR I-2821.

${ }^{8}$ ECJ Opinion 1/91 EEA Agreement [1991] ECR I-6079, para 35. The ECJ furthermore explained that the concept of autonomy was also implicated because concluding the proposed the EEA Agreement would have "the effect of introducing in the Community legal order a body of legal rules which is juxtaposed with a corpus of identically-worded Community rules". As the EEA tribunal was in addition charged with guaranteeing the homogeneous application of these rules, this would, according to the ECJ, have been tantamount to handing over the keys as regards the interpretation of Community law, which, in turn, was contrary to (now) Article 19 TEU.

9 See also ECJ Opinion 1/00 ECAA Agreement [2002] ECR I-349; ECJ Opinion 1/09 Agreement on the European and Community Patents Court, judgment of 8 March 2011, not yet reported.

${ }^{10}$ ECJ Case C-459/03 Commission v Ireland (Mox Plant) [2006] ECR I-4635.

11 Ibid., para 154.
} 
Two years after Mox Plant, in its Kadi judgment, the Court further bolstered the notion of autonomy by indicating that the concept also had a role to play in the absence of jurisdictional competition, the common denominator of Opinion 1/91 and Mox Plant. Indeed, what triggered the concept of autonomy in this case appeared to be exactly the opposite. Had there been an international body capable of reviewing the international measure that was at the roots of the contested regulation in Kadi-a United Nations (UN) Security Council Resolution imposing financial sanctions on terrorist suspects-the ECJ might have refrained from exercising its power of judicial review. ${ }^{12}$ Now that such a dispute mechanism was lacking, however, the Court felt justified to take matters into its own hands; that is, to check whether the regulation at issue comported to European fundamental rights standards. Accordingly, what spurred the ECJ's appeal to the autonomy of the EU legal order was not so much a somewhat narrow concern for its exclusive jurisdiction, as a more general and more profound concern for the constitutional integrity of this legal order. ${ }^{13}$

By firmly linking the concept of autonomy to the "municipal" nature of the EU legal order, the Court seems to have come full circle in Kadi as regards the claims it had made half a century before in Van Gend and Costa. ${ }^{14}$ However, even if it is clear that there is an intrinsic connection between internal and external autonomy, ${ }^{15}$ the exact meaning and scope of the notion are still surrounded by some uncertainty. For instance, in the same sentence in which it refers to "the autonomy of the Community legal system", the Court in Kadi also explains that the exclusive jurisdiction conferred on it by the Treaty forms "part of the very foundations of the Community". ${ }^{16}$ In a recent article, Lavranos has seized on this statement to put forward the claim that the Court has introduced a new concept into the heart of EU constitutional doctrine. ${ }^{17}$ Also, because the ECJ later in the Kadi judgment again mentions the term "the very foundations of the Community", this time not in relation to the notion of autonomy but in relation to the protection of fundamental rights. ${ }^{18}$ Thus, according to Lavranos, the autonomy of the Union legal system

12 ECJ Joined Cases C-402/05 P and C-415/05 P Kadi and Al Barakaat International Foundation v Council and Commission [2008] ECR I-6351, paras 318-326. Cf. also Ziegler 2009, 298-302.

13 Ibid., para 316 "(T)he review by the Court of the validity of any Community measure in the light of fundamental rights must be considered to be the expression, in a community based on the rule of law, of a constitutional guarantee stemming from the EC Treaty as an autonomous legal system which is not to be prejudiced by an international agreement".

14 "Municipal" is the word used by AG Maduro in para 21 of his Opinion in the Case to drive home the same message.

15 Any confusion on this point may beforehand have been due to the fact that the English version of Costa speaks of "independent" instead of "autonomous". Other language versions, however, including, as we saw, the French original, consistently speak of "autonome"-French and Dutch—or "autonomen"-German. Cf. Castillo de la Torre 2002, 1390.

16 ECJ Joined Cases C-402/05 P and C-415/05 P Kadi and Al Barakaat International Foundation v Council and Commission [2008] ECR I-6351, para 282.

17 Lavranos 2010, 268-271.

18 ECJ Joined Cases C-402/05 P and C-415/05 P Kadi and Al Barakaat International Foundation v Council and Commission [2008] ECR I-6351, para 304. 
must be understood to constitute one out of several elements that, combined, make up "the essentials of European constitutional law". 19

Is Lavranos right about this? Is autonomy indeed just an element? Although the ECJ has most certainly done a fine job in obfuscating things, in the end this does not seem to be a convincing explanation. For one thing, Lavranos fails to specify what autonomy means. He lists the concept alongside other notions such as the allocation of powers fixed by the EU Treaties and the Court's exclusive jurisdiction, which is a rather curious thing to do, since, as we saw earlier, the ECJ in past judgments explicitly linked these notions to the autonomy of the EU legal order. Another thing is that the concept of "the very foundations of the" (now) EU is also not as new as Lavranos alleges it to be. In fact, the notion was already present in the Simmenthal decision. ${ }^{20}$ And even in Costa, the Court uses an expression that is very similar to the phrase "the very foundations". According to the ECJ in that case, "the law stemming from the Treaty, an independent source of law, could not (...) be overridden by domestic legal provisions (...) without the legal basis of the Community itself being called into question". ${ }^{21}$

In retrospect, the Court's circular reasoning in Costa seems to convey a message that might have become lost along the way. Namely, that both the concept of autonomy and the concept of "the very foundations of the" Union legal order basically refer to the same thing. For the reason why according to the ECJ in Costa "the legal basis of the Community itself" would be called into question, if national law would be able to prevail over Treaty norms, is precisely that this is an independent legal basis. If this understanding is correct, it simply does not add up to perceive the notion of autonomy as a quantitative component of the Union legal order. Rather, it denotes the quality of this legal order. As such, the concept can exhibit different features, which will depend on the circumstances of the case. In any event, the bottom line of this argument is that autonomy is not exactly in the same league as, say, primacy, fundamental rights protection or judicial review, but forms the premise upon which such fundamental principles of EU law are built.

\subsection{Autonomy as a Precondition for Unity}

The focus of this book is whether it is still meaningful to speak of the autonomous nature of EU law, while anyone can see that the Union (and its Member States) is to an ever larger degree entangled with the international legal order and dependent on the norms that this order, in particular several international organisations, produces. Is it, with that in mind, really necessary to set out in relatively great detail how the

19 Lavranos 2010, 271.

20 See ECJ Case 106/77 Amministrazione delle Finanze dello Stato v Simmenthal SpA [1978] ECR 629, para 18.

21 ECJ Case 6/64 Costa v ENEL [1964] ECR 585, at 601 (emphasis added). 
autonomy claim which the ECJ occasionally puts forward to distance the EU from the world at large is conceptually related to the inner functioning of the EU legal order? Arguably, yes. The reason for this is that without such an elaboration one might lose sight of the basic rationale behind the concept of autonomy: concern for the unity of the EU legal order and, related to that, for the uniform application of its rules. ${ }^{22}$ As the cases discussed in the previous section show, this concern can have different faces. Vis-à-vis national law (Costa), on the one hand, the motive of unity is enveloped in the principle of primacy's aim to prevent significant distortions as regards the application of EU law in the Member States. Vis-à-vis international law, on the other hand, the motive is inherent in both the Court's desire to remain in control of the interpretation and application of EU norms (Opinion 1/91 and Mox Plant) and in its belief that international norms should not be allowed to make serious inroads into the rule of law underpinning the Treaties (Kadi). In the end, however, all these variations boil down to the same fundamental consideration: i.e., that according to the ECJ, the EU forms a unified, self-referential legal order, with its own internal claim to validity, which, at a minimum, is no longer part of the mainstream of international law. ${ }^{23}$

As we have seen, the Court does not explicitly mention the concept of autonomy very often. ${ }^{24}$ However, if the concept is indeed foundational in character and so closely linked to the unity of the Union legal order, the conclusion should be that, even if the constitutional core of EU law is not at risk, the notion is never far away when the ECJ has to decide on a matter that concerns the relationship between Union law, on the one hand, and international law and/or national law, on the other. Take the manner in which the Court handles international norms to which the EU, by concluding a treaty or otherwise, has committed itself. ${ }^{25}$ As a rule, upon becoming binding on the Union, such norms automatically start to form

\footnotetext{
22 See extensively on the relationship between autonomy and unity: Barents 2004.

23 To be sure, one may question if it is sensible to highlight that the ECJ claims that the EU constitutes a self-referential legal order and, in particular, that this sets the EU apart from (mainstream) international law. What about (other) international organisations, one might argue. Should they not also, in an ever more fragmented world, be perceived as autonomous unities with corresponding internal claims to validity? As will be discussed in more detail below, in Sect. 2.4, this reading neglects the fact that there is also a national dimension to every discussion on the nature of international law. Accordingly, what really sets the EU apart from (other) international organisations is that its most important legal spokesperson, the ECJ, claims that the Treaties, of which it is the guardian, derive from an autonomous source.

${ }^{24}$ To my knowledge, apart from the four cases discussed in the previous section, there are only three other cases in which the ECJ explicitly mentions the concept of autonomy. These cases are: ECJ Case 11/70 Internationale Handelsgesellschaft [1970] ECR 1125; ECJ Opinion 1/00 ECAA Agreement [2002] ECR I-349; ECJ Opinion 1/09 Agreement on the European and Community Patents Court [2011] ECR I-0000.

${ }^{25}$ See extensively Holdgaard 2008, 185-194.
} 
"an integral part" of EU law. ${ }^{26}$ This means that they are accorded a privileged position within the EU hierarchy of norms - above secondary rules and national law-and, provided that direct effect is granted, that they can be used to test the validity of these two latter categories. ${ }^{27}$ At the same time, however, the Court has made clear that an incorporated international measure has to conform to primary law. ${ }^{28}$ Accordingly, regardless of the nature or the authorship of an international norm, "in the final analysis", as AG Maduro remarked in Kadi, "the Community Courts determine the effect of international obligations within the Community legal order by reference to conditions set by Community law". 29

Furthermore, after being received into the EU legal order, international norms normally undergo a process of "Unionisation". ${ }^{30}$ In short, this means that such norms will, as far as possible, be treated in the same fashion as normal EU norms. This particularly resonates at the level of the Member States. Agreements concluded by the Union are binding upon the Member States as a matter of EU law. ${ }^{31}$ As a result of this, these agreements profit from the same principles which accompany normal European norms, and flow into the domestic legal systems of the Member States unopposed. ${ }^{32}$ Moreover, when a national court has doubts as to the interpretation or validity of a provision in such an agreement, it is bound to place these before the ECJ, which, by virtue of Article 19 TEU, regards itself as the final arbiter in this respect. Sometimes the Court is forced to perform a balancing act. This is the case when it is confronted with a provision in a mixed agreement that does not fall squarely within the EU's external competence to conclude. Recent case law has shown that in such a situation the ECJ may decide to leave the question of which

\footnotetext{
26 ECJ Case 181/73 Haegeman v Belgian State [1974] ECR 449, para 5. By way of this incorporation, the Court has later explained, the Union intends to show third parties that it is a reliable international partner. See ECJ Case 104/81 Kupferberg [1982] ECR 3641, para 11. The legal basis of this incorporation is Article 216(2) TFEU. As the ECJ recently explained in Case C-366/10 The Air Transport Association of America and Others, judgment of 21 December 2011, not yet reported, paras 101-102, the legal basis for the binding character of customary international law is Article 3(5) TEU, which provides that the EU is to contribute to the strict observance and the development of international law.

27 ECJ Joined Cases C-402/05 P and C-415/05 P Kadi and Al Barakaat International Foundation v Council and Commission [2008] ECR I-6351, para 307.

28 Ibid., para 308. See also e.g. ECJ Case C-327/91 France v Commission [1994] ECR I-3641; ECJ Joined Cases C-317/04 and C-318/04 Parliament v Council and Commission (PNR) [2006] ECR I-4721.

29 Ibid., para 23 of the Opinion of AG Maduro.

${ }^{30}$ Cf. Peters 1997, 34-35; Tietje 2008, 58-59; Van Rossem 2012, 68-69.

31 Article 216(2) TFEU. See also ECJ Case 104/81 Kupferberg [1982] ECR 3641, para 13.

32 Initially, a large number of Member States vehemently protested against this "Unionisation" of international agreements. See Mendez 2010, 1720-1723.
} 
effects should be given to the relevant provision to a national court, while at the same time retaining overall jurisdiction to determine whether this is a proper course to follow. ${ }^{33}$ In this way, both the coherence of the EU legal order and the pluralist ethos which underlies European constitutionalism can be preserved.

Concerns for the unity-and therefore implicitly also for the autonomy —of EU law also play a role when the Court decides not to receive international law within the Union legal order. This occurs when the ECJ comes to the conclusion that an external norm lacks binding force in the EU. ${ }^{34}$ The main "casualties" of this approach are treaties that are concluded by the Member states without the participation of the EU. When such a treaty collides with a European norm, it is basically expected to give way. ${ }^{35}$ An exception in this regard exists for international agreements that were concluded by the Member States before the entry into force of the Treaty of Rome. ${ }^{36}$ As Article 351 TFEU points out, this category is immune to the effects of European law. However, this immunity has its limits. As the Court explained in Kadi, Article 351 TFEU "may under no circumstances permit any challenge to the principles that form part of the very foundations of the Community legal order". 37 In addition, Article 351 TFEU asks Member States to do everything in their power to eliminate incompatibilities that may arise between the EU Treaties and prior agreements. ${ }^{38}$ In the end, therefore, even where the Treaties appear to take the wider international context into account, it is largely up to the Member States to worry about the consequences of a treaty conflict.

\footnotetext{
33 See ECJ Case C-431/05 Merck [2007] ECR I-7001, paras 30-38. In Merck, the Court explained that mixed agreements, just as "purely" EU international agreements, are received into the Union legal order as a whole. Previously, the ECJ only stressed that mixed treaties had the same status in the Union legal order as purely EU agreements "in so far as" the provisions of such treaties fell within the scope of EU law. (See e.g. ECJ Case C-239/03 Commission v France (Étang de Berre) [2004] ECR I-9325, para 25.) Consequently, it could be argued that provisions of a mixed agreement which fell outside the scope of EU law did not form part of the Union legal order; a point of view that, for various reasons, was quite problematic. See Van Rossem 2012, 69-74; 83-85. Cf. also ECJ Case C-240/09 Lesoochranárske zoskupenie VLK v Ministerstvo životného prostredia Slovenskej republiky judgment of 8 March 2011, not yet reported, paras 29-36.

${ }^{34}$ See the recent ECJ Case C-533/08 TNT Express Nederland BV $v$ AXA Versicherung AG [2010] ECR I-04107, paras 59-62.

35 See e.g. ECJ Case 181/80 Arbelaiz-Emazabel [1981] ECR 2961, paras 30-32. See further Schütze 2009, 323-329. It should be noted that the principle that an international norm which does not bind the EU is not received into the EU legal order is not only relevant in the event of a treaty conflict, but also when such an international norm is invoked for purely interpretational purposes. See ECJ Case C-533/08 TNT Express Nederland BV v AXA Versicherung AG [2010] ECR I-04107, paras 61-62. Critical: Klabbers 2009, 142-148.

36 Or, if a Member State has acceded to the EU at a later date, before the moment of accession.

37 ECJ Joined Cases C-402/05 P and C-415/05 P Kadi and Al Barakaat International Foundation v Council and Commission [2008] ECR I-6351, para 304.

38 The Court has made clear that this obligation might even entail a duty to denounce an anterior treaty. See e.g. ECJ Case C-62/98 Commission v Portugal [2000] ECR I-5171. Cf. further Koutrakos 2006, 304-316.
} 
That an international norm has to be (formally) binding upon the EU before it can create effects within the European legal order appears logical. The Union is a separate international legal person; not a mere vehicle for its Member States. Related to this and more importantly is that an accommodating attitude vis-à-vis international norms that are not binding upon the Union could shatter the integrity of the EU legal order. If the ECJ were to integrate such norms, Member States could feel invited to impose their will through the backdoor. ${ }^{39}$ The supremacy of secondary Union law would, after all, be defused in this way. Evidently, this could impair the process of market integration. As we shall see, from the perspective of international law there are serious downsides to this story. ${ }^{40}$ What counts for now, however, is the perception that the Court's approach towards international law seems to be deeply influenced by its reasoning in Costa, and thus ultimately leads back to the idea of the EU as an autonomous legal order. ${ }^{41}$

\subsection{Verfassungsverbund, Self-Contained Regime or Sovereignty in Disguise?}

The view that fundamental principles such as primacy and fundamental rights protection are, to a significant extent, informed by the concept of autonomy and, by the same token, a concern for unity, is not uncontested. That these principles followed the idea of autonomy, one might argue, was especially true in the early days of the integration process, when the Community sought to impose itself on the Member States, and the ECJ needed to cover the rather naked claim of normative authority it had made in Costa with some legitimacy. ${ }^{42}$ Arguably, however,

\footnotetext{
39 See Halberstam and Stein 2009, 62-63. Furthermore, cf. ECJ Joined Cases C-402/05 P and C-415/05 P Kadi and Al Barakaat International Foundation v Council and Commission [2008] ECR I-6351, para 31 of the Opinion of AG Maduro, who develops a similar argument with regard to Article 351 TFEU (ex Article 307 TEC).

${ }^{40}$ See Sect. 2.6.

41 This pattern can also be discerned in what, according to some, constitutes the most momentous Court decision in the field of EU external relations: the AETR judgment. In this case, the ECJ developed the doctrine of parallelism, according to which there is an intimate connection between what happens at the internal level and the external level. Specifically, when the EU effectuates its internal competence to lay down common rules, the Member States, even in the absence of express external competence, are no longer allowed to undertake independent international action if this action affects those rules. This is because, under such circumstances, "the conclusion of an agreement by the Member States is incompatible with the unity of the common market and the uniform application of Community law". See ECJ Case 22/70 Commission v Council (AETR) [1971] ECR 263, para 31. Cf. also ECJ Opinion 1/03 Lugano Convention [2006] ECR I-1145. See on the transformational character of the AETR judgment e.g. Koutrakos 2006, 84-85; Eeckhout 2010.

42 See Poiares Maduro 2005, 334-343.
} 
today the relationship between the Union and the Member States has stabilised, so that the incentive for the Union to impose itself on the Member States has lost its sharp edges. In line with this, it has been argued that the rule of law has shaken off its earlier narrow focus on unity and now also- - perhaps even foremost-functions as a vehicle for principles promoting diversity. To capture this development, it has become a trend to perceive the whole of the EU and Member States as a Verfassungsverbund - a constitutional compound. ${ }^{43}$ In this Verfassungsverbund, formal hierarchy is absent. Instead, it rests on general constitutional principles that all actors have in common. ${ }^{44}$ As a result, the concept of autonomy (and, mutatis mutandis, national sovereignty) is effectively sidelined.

Has the European legal order indeed turned fundamentally pluralistic? While this portrayal may seem attractive, it is suggested that this is not the case; at least not in a strictly normative sense. From a theoretical point of view, the implication of the Verfassungsverbund thesis is that the European legal order lacks an Archimedean point. Instead, legal unity is supposed to result from dialogue. Conceptually, such an arrangement is difficult to fathom. Hierarchy serves a purpose. Without it, it becomes difficult to establish the validity of a norm. ${ }^{45}$ General principles will not be able to solve this matter. At least not as long as there is uncertainty about the rationale-in a democratic polity the "common good"with which these principles correspond. The Verfassungsverbund theory seeks to provide in such a rationale by pointing to the citizens of the Union, who, thanks to an unorthodox conception of sovereignty, would be in a position to choose at which level they intend to achieve their political goals. ${ }^{46}$ Ultimately, however, in the case of constitutional conflict, clarity is needed on the question of which perception of the "common good" is to prevail. ${ }^{47}$

Apart from theoretical considerations, there are also reasons of a more pragmatic nature to reject the Verfassungsverbund thesis. As a general matter, one can

\footnotetext{
43 Von Bogdandy 2010, 38-39. See also Mayer 2010; Pernice 2009; Besselink 2007.

44 The heterarchical nature of the European legal order would e.g. follow from a combined reading of Article 2 TEU, which lays down the values on which the Union is based, and Article 4(2) TEU, the national identity clause. See e.g. Von Bogdandy and Schill 2011; Pernice 2011. See for the case law that is often cited in support of the idea that the Union has overcome absolute primacy e.g. ECJ Case C-36/02 Omega Spielhallen [2004] ECR I-9609; ECJ Case C-208/09 Sayn-Wittgenstein, judgment of 22 December 2010, not yet reported.

45 See e.g. Kelsen 2007, 123-124; Richmond 1997, 388-392. Cf. also Baquero Cruz 2008, $415-416$.

46 Pernice 2009, 374-378. Cf. also Hoeksma 2011.

47 This critique is not just about bringing the vexed issue of Kompetenz-Kompetenz, the usual bedfellow of legal hierarchy, into the spotlight. There are also good legal philosophical reasons to question the particular sovereignty conception of the Verfassungsverbund theory. Pouvoir constitué and pouvoir constituant, the two traditional constitutional notions in norm-fact discussions, are mutually constitutive. Just as a norm needs a sovereign in order to become valid, a sovereign needs a norm which designates the sovereign as sovereign. In the Verfassungsbund, such a norm is lacking. Therefore, its citizens stand on soggy ground. See on the paradoxical nature of sovereignty e.g. Lindahl 2007; Walker 2002, 340-341; Heller 2002, 265-279.
} 
object that the theory does not reflect actual legal practice. Although there are some signs that suggest otherwise, ${ }^{48}$ most judges continue to frame their rulings against the background of their own legal orders. This does not mean that there is no interaction or dialogue between the different judicial actors. Indeed, there are several examples of judicial decisions and other legal developments, at the Union and national level, which indicate that the European legal space has grown increasingly pluralistic over the years. ${ }^{49}$ Crucially, however, these encounters seem to have a factual rather than a normative basis. There is no "Law of Laws" that binds EU law and national law together. ${ }^{50}$ Consequently, concepts such as autonomy and national sovereignty, however shaky they may have become empirically, remain essential in a conceptual and normative sense.

Asserting that autonomy continues to be a relevant paradigm for the Union is not the end of the story. What still needs to be determined is what fabric this particular claim is made of. There are, grosso modo, two schools of thought in this respect. One school that sees the EU as a highly specialised self-contained regime in international law, and another school that maintains that the umbilical cord between EU and international law has been cut. According to the first view, the fact that the ECJ in Costa declared that the EEC Treaty "created its own legal system" does not entail that the Union has completely lost its international feathers. ${ }^{51}$ Just as other international organisations that are equipped with independent decision-making competences, the EU, if one follows this path, can be said to have a "dual character". 52 Outwardly, it acts as a unity. Constitutionally, however, it is still dependent on the Member States. Autonomy, as a result of this, has a derivative status. ${ }^{53}$

\footnotetext{
48 In particular the Lisbon judgments of the Czech Constitutional Court spring to mind. See Komárek 2009 for excerpts from a translation of the second Decision. See, from the same Constitutional Court, however also Pl. ÚS 5/12 of 31 January 2012 Slovak Pensions, the first time ever (!) a judgment by the ECJ was declared ultra vires by a national court.

49 See e.g. Voßkuhle 2010; Meij 2010, respectively the current President of the German Constitutional Court and a judge of the General Court of the ECJ.

50 See e.g. Barents 2009, 444-445; MacCormick 1995, 265. Of course, this does not mean that the EU and the Member States live in complete isolation of each other. It does mean, however, that there is no constitutional "bridge" which overarches and connects the two competing narratives put forward by, on the one hand, the ECJ and, on the other, several constitutional courts. Accordingly, this view is also at variance with more "pluralistic" versions of the idea of constitutional pluralism, such as Miguel Maduro's theory of contrapunctual law, which argue that while the concept of autonomy cannot be sidelined, as supporters of the Verfassungsverbund idea maintain, there has to be some normative code that ties the aforementioned competing narratives together. See for a brief overview of the different strands which one encounters within the school of constitutional pluralism: Avbelj 2008, 11-19.

51 De Witte 2010. See also e.g. Hartley 2001.

52 Cf. Dekker and Wessel 2010, 160-163.

53 This is also the line that the German Constitutional Court takes. See e.g. BVerfGE 89, 155, 190 Maastricht.
} 
Of course, most proponents of the "internationalist" school do not deny that the EU has acquired certain constitutional features. Neither are they failing to see that, in many respects, the Union is a very atypical model for an international organisation. What they do say, however, is that, to date, there has not been a seismic shift which has somehow transformed it into a sovereign entity. The founding documents of the Union, it is argued, still are and always have been treaties. And when it comes to amending these treaties, only the Member States are competent, so that it is not plausible to plead that they are in the same league as a genuine, German-style Verfassungsvertrag. ${ }^{54}$ According to the "internationalist" school, all this means that, in the final analysis, the EU has not (yet) contracted itself out of the public legal order of international law. Consequently, in case primary law does not provide an adequate solution, strictly speaking, a fall-back on principles of state responsibility is, for example, still an option for the Member States. ${ }^{55}$

Undeniably, commentators who continue to observe the Union through the prism of international law have some strong cards to play. The dominant view of European legal scholars, nonetheless, is that this reading should be rejected. The main argument in this respect is that such an approach just does not have any explanatory value anymore with regard to the EU. In addition, it is maintained that it unnecessarily holds on to the binary scheme state-international organisation. A more specific objection to the international law prism is that once one conceives of autonomy as a derivative concept, the unity thesis of the ECJ becomes unsteady. To be sure, selfreferentiality is also a key notion in self-contained regimes. From the perspective of national law, however, in that case self-referentiality will always be contingent on domestic law. In other words, if a constitution allows this, national authoritiesjudges, lawmakers - are, within the confines of their own legal order, free to break into such a regime. ${ }^{56}$ As expounded earlier, the reason why the Court came up with its particular autonomy conception in the first place was to prevent this. Thus, it would make little sense to keep considering the EU in internationalist terms.

If one discards an international reading of the Union, the next question is how, then, to perceive the autonomy claim put forward by the ECJ. Assuming that the Verfassungsverbund thesis does not add up, only one credible alternative remains: that autonomy is a disguised claim to sovereignty. Many scholars and practitioners find this option disturbing to contemplate. ${ }^{57}$ The reason for this is obvious: sovereignty is intimately, according to some even inextricably, tied up to the (nation) state. And that is a vision that, allegedly, is contrary to the spirit of European integration. ${ }^{58}$ This criticism is not wholly unjustified. Indeed, fully embracing the notion of

\footnotetext{
${ }^{54}$ See De Witte 2010, 144-145. Cf. further Chap. 4 of this volume.

55 See Simma and Pulkowski 2006, 516-519.

56 Which, of course, is an option that many national constitutional courts still leave open vis-àvis EU law. See Grabenwarter 2010 for an overview of the most important case law in this respect.

57 See e.g. Barents 2004; Schiemann 2007.

58 See e.g. Weiler 1991, 2481.
} 
sovereignty is bound to gravitate towards something resembling statehood. Sovereignty is about ultimate authority. As such, in contrast to what some commentators contend, it is not something that can be divided or pooled. ${ }^{59}$ This is only part of the story, though. Sovereignty is not just a naked political category programmed to control or even frustrate the orderly functioning of the law. Constitutionally speaking, it is first and foremost indissolubly linked to the legal order which it purports to explain. ${ }^{60}$ Crucially, to be able to speak of sovereignty at all, a constitutional act is needed to indicate that there is such a thing as a "sovereign". 61 The concept, accordingly, constitutes a paradox, which is caught up in an act of circular reasoning.

Constitutional lawyers usually do not like to dwell on the question of what lies beyond the horizon of a legal order. ${ }^{62}$ At some point, constitutional reasoning has to stop, the argument goes. Yet when one maintains that the concept of EU autonomy implies that the umbilical cord with international law has been severed, it is important to correctly explain how this is possible. Norms cannot explain their own validity. Moreover, as we shall see in the next two subsections, it matters which of the two paradigms - international or municipal-is chosen. Although this conception is not problem free, it is submitted that, all things considered, it is most convincing to opt for a narrative which takes sovereignty as a model in this respect. ${ }^{63}$ Critical is that the ECJ puts forward a claim to the supreme authority of

59 See, approving of the idea of divided sovereignty, e.g. Oeter 2010, 63-65; Schütze 2009, 6973. Admittedly, the founding judgments of the ECJ_Van Gend and Costa-prima facie also seem to lend credence to the view that, in the context of European integration at least, sovereignty has become something that can be pooled or shared. In ECJ Case 6/64 Costa v ENEL [1964] ECR 585 , for example, the Court stated that the Community enjoys "real powers stemming from a limitation of sovereignty or a transfer of powers from the States to the Community" (emphasis added by the author). On closer consideration, however, it appears doubtful that this passage should be interpreted as meaning that sovereignty as such has been divided. Rather, it conveys the message that the Member States no longer exercise all powers usually associated with the concept of sovereignty. This is also borne out by the German and French versions of the Decision, which, respectively, speak of "Hoheitsrechten and Souveränitätsrechte" and of "droits souverains" which are limited by European integration. See De Witte 1998, 277.

${ }^{60}$ See Böckenförde 1991, 107-112.

61 See supra n. 47.

62 See e.g. Von Bogdandy 2010, 14-16; Peters 2010, 50-54.

63 In particular there is a legitimacy issue. Even if the Court's claim has over the years been strengthened by democratic and institutional developments, there is still no constitutional process to back this claim up in an adequate fashion. Until that changes, the "market citizen" to whom the ECJ alluded in Van Gend will remain a rather pale figure. Another reason why it might be problematic to perceive the EU as a sovereign entity is the fact that one of its policy areas, the former second pillar, is still very much intergovernmental in nature and largely devoid of supranational features such as direct effect and judicial review. However, while this aspect certainly makes the autonomy claim put forward by the ECJ less strong, it does not appear to undermine the main tenet of this claim-i.e. that the Union constitutes a unity. Cf. e.g. Von Bogdandy 2010, 26-28. 
EU law over national law. ${ }^{64}$ National courts can discard this claim, but not conclusively unsettle it. For, in turn, their sovereignty narratives are also based on a claim. ${ }^{65}$ Admittedly, these claims enjoy more legitimacy than the claim put forward by the ECJ. Normatively speaking, however, this does not entail that the national version of the "truth" regarding European constitutionalism is per se right. At the end of the day, maybe the best way to put it, is that there are two of such versions, and that until this matter has been sorted out, the question of sovereignty is effectively "suspended" within the European legal order. ${ }^{66}$

\subsection{Freedom That is Organised by International Law and Committed to it}

On 30 June 2009, the German Constitutional Court in Karlsruhe gave judgment in a case in which it was asked to review the constitutionality of the Lisbon Treaty. ${ }^{67}$ Characteristically for tidings that come from Karlsruhe on the process of European integration, the Decision received a lot of attention and, although it raised no insurmountable obstacles to ratifying the Treaty, also a predictable amount of criticism by legal scholars. ${ }^{68}$ Generally, this criticism seems to have been

${ }^{64}$ Legal scholars who seek to downplay the nature of the claim which the ECJ makes in Van Gend and Costa often refer to the fact that the supremacy rule does not result in the annulment but in the disapplication of national law. (See ECJ Joined Cases C-10/97 to C-22/97 Ministero delle Finanze v IN.CO.GE'90 Srl [1998] ECR I-6307, para 21.) It is respectfully submitted, however, that this is not a convincing argument. The sanction of nullity might be an important argument in favour of hierarchy, but the absence thereof does not provide conclusive evidence that such hierarchy is lacking. See e.g. Sillen 2010, who analyses constitutional practice in the United States and in the Netherlands and shows that, as a general rule, a judicial decision by an American or Dutch judge that a national norm conflicts with a norm issued by a state or provincial body does not render the latter norm non-existent.

65 See e.g. Walker 2003b; Lindahl 2003.

${ }^{66}$ Cf. Schmitt 2003, 366-379, who to this end developed the concept "Bund", a constitutional form somewhere in between a federal state (Bundesstaat) and a confederacy (Staatenbund). According to Schmitt, because the issue of sovereignty is deliberately being left open in a Bund, this construction is inherently unstable. For in the final analysis a Bund is founded on a "Widerspruch". Typical for a Bund, accordingly, is that there is no distinctly constitutional way to solve existential conflicts between the whole and the parts. Indeed, in case such existential conflict might occur-something Schmitt elsewhere famously called a "state of exception"-we can expect to discover who the real "sovereign" is. Even though Schmitt came up with his Bund theory long before the process of European integration started, this notion arguably constitutes a framework which is remarkably apt for understanding the current state of constitutional affairs in Europe. In particular, because it nicely illustrates that there are limits to what constitutional law can explain and embrace. Indeed, in a way it could be argued that we are experiencing a state of exception right now! After all, what else is the Euro crisis than an existential conflict about the future of the EU?

67 BVerfGE 123, 267 Lissabon.

68 See e.g. Bieber 2009; Tomuschat 2010. 
undeserved. In Lissabon, the Constitutional Court struck a markedly different tone than it had done a little less than two decades before in its Maastricht ruling. So much so that the judgment could even be said to fit in a pluralist scheme. ${ }^{69}$ Particularly interesting for our purposes is a not much commented upon paragraph midway through the ruling in which the German Court explains what it understands by sovereignty. According to Karlsruhe, the German Constitution "abandons a high-handed concept of sovereign statehood that is sufficient unto itself and returns to a view of the state authority of the individual state which regards sovereignty as "freedom that is organised by international law and committed to it".,"70

Defining the autonomy of the EU legal order as "freedom that is organised by international law and committed to it" would perhaps be stretching things. For the German Court subsequently firmly links "freedom" to "self-determination".71 Nonetheless, it is submitted that this particular understanding offers a promising point of departure for dealing with the autonomy thesis. At least in a theoretical sense, it shows that sovereignty does not necessarily have to be equated with "political Machiavellianism". ${ }^{72}$ To be sure, the fact that the EU cannot turn its back on international law is beyond dispute. As AG Maduro put it in Kadi, the Union's "municipal legal order and the international legal order (do not) pass by each other like ships in the night". ${ }^{73}$ However, at the same time, several commentators also feel that the EU, through its legal spokesman the ECJ, has taken on an increasingly antagonistic attitude vis-à-vis international law in recent years. ${ }^{74}$ Inextricably related to this development, the prevailing sentiment seems to be, is the progressive constitutionalisation of the Treaties. Thus, one could argue, the more constitutionally mature the EU becomes, the more protective the shield of the concept of autonomy in the face of the international legal order. ${ }^{75}$

Whether there has really been a "rupture" in the case law of the Court regarding the way the EU positions itself against international law can be debated.

\footnotetext{
${ }^{69}$ Cf. Thym 2009, 1809-1812. See also the German Constitutional Court's recent decision in Honeywell, judgment of 6 July 2010, 2 BvR 2661/06, in which it responded, in a very accommodating manner, to the ECJ's Mangold jurisprudence, see ECJ Case C-144/04 Werner Mangold v Rüdiger Helm [2005] ECR I-9981.

70 Lissabon, para 223 (citing the 19th century German legal scholar Ferdinand van Martitz).

71 Ibid., para 224.

72 Ibid.

73 ECJ Joined Cases C-402/05 P and C-415/05 P Kadi and Al Barakaat International Foundation v Council and Commission [2008] ECR I-6351, para 22 of the Opinion of AG Maduro.

74 See e.g. Gattini 2009, 224-235; De Búrca 2010, 22-26.

75 Cf. e.g. Lavranos 2010.
} 
In fact, there is also much to be said for the conclusion that judgments which are often singled out in this respect-Mox Plant, Kadi and Intertanko ${ }^{76}$-are actually very much consistent with past jurisprudence. ${ }^{77}$ What matters here, however, is the impression that is created by such statements. Is a constitutional approach to autonomy indeed bound to lead to the demise of international law within the Union legal order? In a conceptual sense, unmistakably the concept grows stronger as the EU constitutionally evolves. In what appeared to be an effort to justify its own way of reasoning, this was recognised by the German Constitutional Court when in its Lissabon Urteil it referred to the ECJ's handling of the Kadi case. ${ }^{78}$ Yet Karlsruhe also made clear that this fact by no means gives a domestic legal order carte blanche to frustrate international law. Quite the reverse, only "in a borderline case" is it acceptable to place "the assertion of its own identity as a legal community" above a commitment that is otherwise respected. ${ }^{79}$ This is because in such a situation "the ordre public as the boundary of commitment under treaty" comes into view. ${ }^{80}$

It is important to note that the German Court's conception of the relationship between sovereignty and international law, in effect, constitutes a paradox. For what Karlsruhe is saying is that sovereignty is at the same time unconstrained (freedom as self-determination) and constrained (organised by international law). This paradox is closely linked to the apparent contradiction which we came across earlier when discussing sovereignty in a purely internal context. Then, the bottom line was that sovereignty is both at the source of constitutional law and in need of constitutional law. Essentially, this is a typical liberal dilemma. During the Middle Ages, societies, at a fundamental level, were understood to be pervaded by a code of natural (divine) law. In marked contrast, with the advent of modernity, social order came to rest, ideally, on the subjective consent of inhabitants who were free of anterior legal bonds. Yet as most thinkers realised, freedom could only be achieved by simultaneously limiting it.

This same mechanism is also at work in the interaction between international law and sovereignty. ${ }^{81}$ On the one hand, as medieval structures broke down after a series of religious wars, scholars recognised that states, the vehicles for the fulfilment of individual liberty, should form the new pillars of the international legal system. As a result, international law could only play a residual role. On the other hand, it was also

\footnotetext{
76 ECJ Case C-459/03 Commission v Ireland (Mox Plant) [2006] ECR I-4635; ECJ Joined Cases C-402/05 P and C-415/05 P Kadi and Al Barakaat International Foundation v Council and Commission [2008] ECR I-6351; ECJ Case C-308/06 Intertanko [2008] ECR I-4057. See also, the recent ECJ Case C-366/10 The Air Transport Association of America and Others, judgment of 21 December 2011, not yet reported.

77 See e.g. Eckes 2012a, 374-377; Van Rossem 2009, 192-202.

78 Lissabon, para 340.

79 Ibid.

80 Ibid.

${ }^{81}$ Here I mainly rely on Martti Koskenniemi's still seminal work From Apology to Utopia. See in particular Koskenniemi 1989, 52-130.
} 
widely believed that there had to exist a preceding, normative code which could override state behaviour. Otherwise, order and, eo ipso, also liberty would remain an empty phrase. But how could entities which claimed to form the source of rules that regulated the conduct between them at the same time be bound by these rules? Just as in the case of the paradox of constitutionalism, this seems to be a puzzle that cannot be solved. What Koskenniemi has called the "ascending" and "descending" pattern of international law are mutually exclusive. ${ }^{82}$ The challenge, therefore, becomes how best to deal with it. As the German Constitutional Court correctly stressed, the key in this respect lies in a combination of openness towards and responsibility under international law $^{83}$ - a course most European states indeed seem to have taken after the end of the Second World War, in particular, of course, on the European continent itself. If a state were to hold on to a "high-handed concept of sovereign statehood that is sufficient unto itself", it would betray the concept's most important function; that of legitimacy. For, again, without a certain degree of universal order, freedom, which since the late 18th century has been the main criterion of legitimacy, cannot be achieved and sustained. ${ }^{84}$

Evidently, the accessibility of this trajectory for the EU is seriously hampered by the fact that it is not a state. Indeed, alongside commentators who conclude that there is an obvious connection between the ECJ's constitutional narrative and its sometimes defensive attitude vis-à-vis international law, there are also writers who, on the contrary, maintain that this attitude should first and foremost be considered in light of the fact that the Union is still in many respects an international organisation. Uerpmann-Wittzack, for example, stresses that whereas nation states such as Germany and France "do not seriously jeopardise their identity if they subject themselves to international obligations", the EU "is a relatively young construction that in essence is considered to be a Community of law". 85 The Union's “aspiration for autonomy, therefore, seems to be an attempt to achieve and strengthen an identity of its own" and "is explicable in that (it) has not yet found its permanent place in the international community". 86

What Uerpmann-Wittzack says certainly makes a lot of sense. Especially when you relate this to the "reality" wherein the EU finds itself at the international stage. Member States sometimes prove to be reluctant to accord the Union an international role which it would deserve on the basis of internal legislative activities. In addition, third parties are not always ready to open treaties or international organisations to the EU. ${ }^{87}$ Hence, it is no wonder that the ECJ occasionally struggles in finding a proper balance between respecting international

82 Ibid., 40-42.

83 See in this sense also e.g. Werner 2004. Further cf. with regard to the German Grundgesetz, Storost 2000.

84 Cf. Peters 2009.

85 Uerpmann-Wittzack 2010, 160. See also Eckes 2012 b.

86 Ibid., 160-161.

87 See Editorial Comments 2011, 3-4. 
law and defending the integrity of the Union's legal order. Even so, it is also clear that these difficulties do not give the Court an excuse to stick "its head in the sand" like an "ostrich" and to act as if the Union is isolated from the outside world. ${ }^{88}$ According to Article 3(5) TEU, the EU "shall contribute to (...) the strict observance and the development of international law". Consequently, the Union is under a legal obligation to do all that lies in its power to enhance the international legal order. Article 21(1) TEU furthermore clarifies that in its action on the international scene, the EU "shall be guided by the principles which have inspired its own creation, development and enlargement". 89 The Treaty thus gives an unequivocal signal as to how the ECJ could try to find the right balance. Perhaps the Union is not based on self-determination, but it certainly has its own identity. In part, as Uerpmann-Wittzack rightly stated, this identity is still in the process of taking shape, but in the meantime it could also serve to locate "the ordre public as the boundary of commitment under treaty".

\subsection{Boundaries}

In the first two sections of this chapter we have already explored in some detail what the ECJ's case law on the interaction between EU law and international law looks like. Now that we have a better view of the premises on which this jurisprudence is arguably based, it is time to put some of these findings to the test. To which extent does the Court currently succeed in finding a right balance between enhancing international law and concern for the identity of the European legal order? And are its occasional "interventions" to protect EU law from the influence of international law really always necessary from the perspective of the concept of autonomy? In what follows, three situations will be analysed: (1) the specific encounter between EU law and UN law in the Kadi case; (2) the relationship between EU law and international agreements only binding the Member States in the light of the ECJ's decisions in Intertanko and, recently, Air Transport Association of America; and (3) the relationship between EU law and binding international agreements in the light of the Mox Plant case. ${ }^{90}$

88 See Klabbers 2009, 219.

89 These principles are: "democracy, the rule of law, the universality and indivisibility of human rights and fundamental freedoms, respect for human dignity, the principles of equality and solidarity, and respect for the principles of the United Nations Charter and international law.".

90 In this analysis, the focus will lie on aspects of the Court's case law that are directly related to the claim of autonomy. This means that the issue of direct effect is being left out of the equation. When it comes to the concrete impact of international law within the EU legal order, this issue is just as vital as the question whether an external norm infringes the integrity of this legal order. To a certain extent, therefore, this choice is somewhat arbitrary. Conceptually, however, there is a clear difference between concerns related to validity (autonomy) and to justiciability (direct effect), and I will stick to that difference for the remainder of this chapter. 


\subsubsection{EU Law v UN Law: Kadi and Fundamental Rights}

In the previous section, it was submitted that the autonomy of the EU, like sovereignty, should be understood as the legal expression of a polity which, in an existential sense, both precedes and presumes international law. In order to come to terms with this paradox, it was furthermore suggested that the EU should strive to accommodate norms which are foreign to its own legal order to the point where these norms threaten what the German Constitutional Court in its LissabonUrteil alternatively labelled "the ordre public" and the "identity" of its polity. To assess whether the ordre public or the identity of the EU is at stake in a given situation, it makes sense first to be guided by its foundational principles, which, as Article 2 TEU clarifies, are pretty much the same as the foundational principles that most states (claim to) hold dear. The obvious case to look at in this respect is Kadi. As the German Court indicated, this seems to have been a typical situation in which it was justified, from a constitutional point of view, to invoke the autonomy of Union law. If the ECJ had accorded immunity to the contested Community regulation at issue because of its origins in UN law, as the CFI had done at an earlier stage of the proceedings, this would have been a blow for the protection of fundamental rights within the Union legal order and, one could add, for fundamental rights protection worldwide. Even so, the decision attracted a great deal of critique; also from commentators who agreed with the result that was reached by the Court. ${ }^{91}$ This criticism particularly focused on the lack of attention for the UN dimension of the disputed measure. Yes, the Court professed due respect for the great responsibility of the UN at the global level. ${ }^{92}$ But all the same it conducted its review in nearly complete isolation of the UN Charter.

Could the ECJ have been forthcoming in its treatment of international law in Kadi? Technically speaking, it is difficult to find fault with the Court's reasoning. Contrary to what the CFI implied, the UN Charter does not seem to impose hierarchy upon domestic legal orders. ${ }^{93}$ Consequently, the ECJ was probably right when it stated that "the principles governing the international legal order under the United Nations" did not preclude it from exercising "judicial review of the internal lawfulness of the contested regulation". ${ }^{94}$ Furthermore, the ECJ has always consistently argued that international norms that form part of the EU legal order have to conform to primary law. Thus it is also hard to argue with its finding that if obligations under the Charter were to be classified in the hierarchy of the EC legal order, this would not give them an unassailable status. ${ }^{95}$ To deviate from this, as the CFI proposed to do,

91 See e.g. Ziegler 2009, 297-298.

92 ECJ Joined Cases C-402/05 P and C-415/05 P Kadi and Al Barakaat International Foundation v Council and Commission [2008] ECR I-6351, paras 292-297.

93 See e.g. Griller 2008, 538.

94 ECJ Joined Cases C-402/05 P and C-415/05 P Kadi and Al Barakaat International Foundation v Council and Commission [2008] ECR I-6351, paras 298-299.

95 Ibid., paras 305-308. 
because the Union "may not infringe the obligations imposed on its Member States by the Charter", would signal that in the final analysis it is no more than a vehicle for the Member States and thus seriously undermine its claim to autonomy. ${ }^{96}$

In spite of this, one is nonetheless left with the feeling that the Court's reading of the situation in Kadi was a bit minimalistic. In particular noteworthy is that it essentially dodged the question whether UN law is indeed binding upon the EU. The hypothetical way in which the ECJ presented this issue suggests that it thought not. ${ }^{97}$ As the EU is not a member of the UN, strictly speaking again, this would come as no surprise. However, from a broader perspective this stance raises questions. For what the Court basically suggests is that the EU is at the same time constitutionally autonomous and exempted from the authority of the world's leading international organisation. To bridge this gap, in future cases the ECJ could consider to materially bind the EU to UN law by succeeding to the Member States' obligations under the Charter as a matter of EU law. ${ }^{98}$ Such a move, a variation on the more expansive International Fruit doctrine and akin to what the CFI proposed in Kadi, would not pierce through any normative relationship on the international plane and only bring about a duty to honour international obligations by the Member States within the confines of the EU legal order. ${ }^{99}$ Arguably, this would be in keeping with the Treaty of Lisbon, which both in Article 3(5) and in Article 21(1) TEU explicitly provides that the Union shall respect the "principles of the United Nations Charter".

In case the Court would have adopted the concept of legal succession under EU law in Kadi, it would have provided itself with a platform from which it could have

\footnotetext{
96 Case T-306/01 Ahmed Ali Yusuf and Al Barakaat International Foundation v Council and Commission [2005] ECR II-3533, para 254.

97 ECJ Joined Cases C-402/05 P and C-415/05 P Kadi and Al Barakaat International Foundation v Council and Commission [2008] ECR I-6351, paras 305-307.

98 Cf. Uerpmann-Wittzack 2010, 154-155; Van Rossem 2009, 213-223.

99 In the International Fruit cases, the Court decided to incorporate GATT into the European
} legal order. It did so on two grounds: first, that there had been a significant transfer of powers from the Member States to the Community in the field of trade policy; second, that third parties allowed the Community to act within the GATT framework. See ECJ Joined Cases 21/72 to 24/72 International Fruit BV v Produktschap voor Groenten en Fruit [1972] ECR 1219, paras 10-18. Several commentators have argued that both conditions have not been fulfilled with respect to UN law. Thus, when the CFI invoked International Fruit in order to bolster its argument that the Community was bound to the Charter in Yusuf and Kadi, it was severely criticised for this. It is submitted, however, that this critique is partly undeserved. For the CFI only used International Fruit to state its case that the Charter had become binding as a matter of European law; and not, as the ECJ had done with regard to GATT, also as a matter of international law. (See Yusuf, paras 242-254). Consequently, while, admittedly, the CFI's reference to International Fruit was rather unfortunate, the frequently heard objection (that the EU is still very much a bystander in the UN framework and, therefore, is in no position to succeed into the Member States' obligations internationally) misses direction. What remains is the argument that there has not been a significant transfer of powers from the Member States to the EU in the field of UN law. Arguably, however, this is also an objection that can be overcome. See to this end Van Rossem 2012, 86-88. Cf. also Eeckhout 2004, 438. 
engaged in a more open discussion as to how the Security Council resolution that formed the basis of the disputed measure comported with international human rights standards. As such, it could have braced itself against subsequent critique that it acted in a "parochial" 100 fashion and contributed to the constitutionalisation of international law. To be sure, the ECJ's case law shows that reception is not an essential prerequisite for interpreting norms which are foreign to the EU legal order. ${ }^{101}$ Generally, however, and especially in recent years, the ECJ is very careful in emphasising that if an international agreement is not binding upon the Union, its hands are tied when it comes to the interpretation of such an agreement, at least in case the validity of secondary Union law is at stake. ${ }^{102}$ Clearly, in Kadi the Court was not concerned that an international norm would affect the validity of a European measure. Still, one could speculate that its uneasiness in discussing the international context of the case more thoroughly somehow related to the fact that the EU is not bound to UN law.

In the meantime, the fact that the ECJ might have missed an opportunity in Kadi to bind the EU to UN law — as the CFI pointed out, already under the old Treaty regime there were strong considerations in favour of such a position-should not distract from the fact that, as a matter of EU law, it was probably right to block the effects of the Security Council Resolution at issue in the EU legal order. Whatever the "parochial" nature of its judgment, in light of Article 6(1) of the former TEU it was clearly defensible to put the individual interest of fundamental rights protection before the more collective interest of international security. Accordingly, the circumstance that a measure originates in the $\mathrm{UN}$ - and not in an average bilateral treaty - should, in the final analysis, not be decisive as to the question whether the EU is obliged to execute an international norm. What counts is if the Court is able to convince its audience that the EU's identity is at stake and, consequently, that the EU would lose out as a polity when, in a concrete case, it would respect international law.

\subsubsection{EU Law v Non-Binding International Agreements: Intertanko and Air Transport Association of America}

It will not always be possible or desirable to apply the concept of succession under EU law, or, for that matter, another alternative that provides an analogy to Article 216 (2) TFEU, normally the legal basis for the reception of international law. ${ }^{103}$

\footnotetext{
100 De Búrca 2010, 4.

101 See with respect to UN law e.g. ECJ Case 374/87 Orkem [1989] ECR 3283; ECJ Case C-84/ 95 Bosphorus [1996] ECR I-3953.

102 See supra n. 41.

103 Before the ECJ starts to contemplate whether it can incorporate an international agreement to which the EU is not formally bound, an important consideration seems to be that all Member States are bound to such an agreement. Another crucial factor is the issue whether there is secondary EU legislation which shows that the Member States have sought to discharge their
} 
Even so, in the search for more harmony between international law and EU lawsomething, again, that the Lisbon Treaty, stronger than before, explicitly encourages - the concept could prove to be a welcome supplement to the ECJ's case law. Right now, the Court shows little flexibility when it is confronted with international law to which the EU is not formally bound; not only in Kadi, but also in a string of other recent cases. ${ }^{104}$ Leaving aside an exceptional case as International Fruit, the Court's current position appears to be that an international norm to which the Union is not formally bound can at best produce a duty to conform interpretation. ${ }^{105}$ Sometimes this is enough for an outcome which is international law-friendly. ${ }^{106}$ In other cases, however, harmonious interpretation will not do the trick. This was for example the case in Intertanko. ${ }^{107}$ Here the Court's refusal to use an external, non-binding norm as a standard for judicial review-in casu the Marpol Treaty on the prevention of ship-source pollution-led to a lack of judicial protection. This is because the contested measure in Intertanko, a directive, could neither be tested as to its validity before the referring national court. ${ }^{108}$

A similar thing occurred in the recent case of Air Transport Association of America, a reference for a preliminary ruling from an English court on the validity of a directive that included aviation activities within the Union's Emission Trading Scheme (ETS). In order to evade the ETS, the applicants, a collection of American and Canadian aviation companies and associations, had, amongst other things, staked their hopes on the Chicago Convention, the founding document of the International Civil Aviation Organisation (ICAO). ${ }^{109}$ According to the applicants, the contested measure contravened the Chicago Convention in two ways. First, it was argued that the EU had exceeded its powers under international law by

(Footnote 103 continued)

obligations under international law into Union law and, at the same time, that there has been a significant transfer of powers. See for various techniques which the Court may apply in this regard (techniques which do not necessarily correspond with the rather one-dimensional approach advocated here): Eckes 2010, 905-915. Cf. also Eeckhout 2009, 2051-2053.

104 See e.g. ECJ Case C-308/06 Intertanko [2008] ECR I-4057; ECJ Case C-188/07 Commune de Mesquer [2008] ECR I-4501; ECJ Case C-301/08 Bogiatzi [2009] I-10185; ECJ Case C-366/10 The Air Transport Association of America and Others, judgment of 21 December 2011, not yet reported. Cf. also ECJ Case C-205/06 Commission v Austria [2009] ECR I-1301; ECJ Case C249/06 Commission v Sweden [2009] ECR I-1335.

105 Cf. Chap. 7 of this volume.

106 See e.g. ECJ Case C-533/08 TNT Express Nederland BV v AXA Versicherung AG [2010] ECR I-04107.

107 ECJ Case C-308/06 Intertanko [2008] ECR I-4057.

108 See ECJ Case 314/85 Foto-Frost [1987] ECR 4199. In addition, the Court also denied direct effect to UNCLOS, another treaty on which the applicants based their claim in Intertanko.

109 ECJ Case C-366/10 The Air Transport Association of America and Others, judgment of 21 December 2011, not yet reported. Other international norms on which the applicants based their claim were: the Kyoto Protocol (binding upon the Union, but no direct effect); the Open Skies Agreement (binding upon the EU and direct effect, but no violation found); and several principles of customary law (binding upon the Union and, rather surprisingly, direct effect, but no violation found). 
adopting a regulatory instrument which is not limited to European air traffic but also covers transatlantic flights. Secondly, the applicants advanced the argument that the Convention required that any comprehensive greenhouse reduction scheme should be negotiated and developed within the framework of the ICAO. The Court, however, did not enter into any substantive reasoning as to the viability of these arguments. It just noted that the EU is not a party to the Chicago Convention and, referring to International Fruit, that there had not been a complete transferral of powers in the field covered by the Convention. ${ }^{110}$

In Intertanko and Air Transport Association of America, the Court's decision not to incorporate an international agreement to which the Union is not formally bound, primarily seems to have stemmed from a desire to defend the unity of the Union legal order. As mentioned earlier, in principle this is a valid concern. ${ }^{111}$ Conceptually, the unity of a legal system is inextricably bound up with its autonomy. Consequently, even when an international norm does not impinge on Article 2 TEU, it might possibly threaten the identity of the Union; e.g. in case such a norm would seriously undermine the functioning of the internal market. Still, given that the Union also aspires to be a responsible international actor, one can wonder if it is really necessary for the ECJ to hold on to the requirement of unity at all costs. While decisions such as Intertanko and Air Transport Association of America may preserve the unity of the Union legal order, they potentially disrupt the unity of other treaty systems, which for their well-being, just as the EU, very much depend on the execution of their norms within domestic legal orders. As the EU is supposed to be more than a normal treaty system, it could accordingly be argued that it would be befitting if the ECJ would occasionally ease its doctrine on the effects of international law within EU law. ${ }^{112}$

As was already noted in the context of Kadi, it should be stressed that more flexibility as regards the question whether an international norm can form part of the EU legal order is not the same as saying that EU law should bow to international law. A decision by the ECJ in Air Transport Association of America to incorporate the Chicago Convention as a standard of judicial review would

\footnotetext{
110 Ibid., paras 62-72.

111 See Sect. 2.3.

112 By fencing off a legislative measure from its source in international law the ECJ also creates a situation in which the Member States can be held responsible for breaching their international obligations. It has been argued that Member States are not particularly worried about this prospect; probably because they realise that this is the price they have to pay for maintaining a presence on the international plane. See Schütze 2006-2007, 437. Could it therefore be that the ECJ's concealed appeal to the concept of autonomy in Intertanko, in a somewhat twisted way, may also be explained as a token of respect for the distribution of competences between the Union and the Member States? While this option cannot be excluded, it seems unlikely that such a consideration is at the forefront of the Court's mind when it decides not to interpret an international norm. More plausible seems to be that, alongside the general concern for the integrity of EU law, it sends a signal to the Member States and perhaps also to third parties that they should pave the way for a formal accession of the EU to international organisations and treaty systems from which these norms derive. Cf. Hoffmeister 2010, 267.
} 
probably not have made the invalidity of the disputed directive a foregone conclusion. Likewise, in Intertanko, the reception of Marpol in EU law would, as the Opinion of AG Kokott in the case shows, also not necessarily have helped the applicants, a group of shipowners that wanted to escape a stricter liability regime that was created by EU law. ${ }^{113}$ The main point here is that by incorporating the Chicago Convention and Marpol into the EU legal order, the Court could at least have discussed whether both EU schemes comported to international law. As such, it would not only have remained more within the range of its commitment to respect international law, but also of its commitment to maintain an effective level of judicial protection.

Arguably, the option of reception was not altogether unrealistic in both cases. Both the Chicago Convention and Marpol are international agreements to which all Member States are parties, thus removing an important obstacle as regards the application of these treaties in the EU legal order. Moreover, there is a fair amount of EU legislation in the fields covered by these instruments. Finally, in the specific case of Intertanko, the disputed directive explicitly stated that it purported to implement the treaty which according to the Court fell outside its jurisdiction to interpret. ${ }^{114}$ Of course, it is true that a more forthcoming attitude by the ECJ on this subject could possibly reward a lack of stringent liability or regulatory regimes at a global level and, mutatis mutandis, thwart the EU's ambitions to fulfil an exemplary role on this plane; something which can also be said to make up the identity of the Union. After all, had the Court for example found that the ETS does in fact violate the Chicago Convention, it would have had no choice but to invalidate the measure including aviation activities within this scheme. Then again, right now one is left to speculate that the Decision by the ECJ has been partly motivated by the fact that such a result would have been "politically or morally undesirable". ${ }^{115}$ And that in itself does not seem to be a normatively acceptable consideration.

\footnotetext{
113 In her Opinion in Intertanko, AG Kokott tried to circumvent the non-binding nature of Marpol as regards the EU by developing an argument in which this treaty was incorporated through UNCLOS, another treaty on which the applicants had based their claim and which was binding upon the EU. See ECJ Case C-308/06 Intertanko [2008] ECR I-4057, paras 46-70 of the Opinion of AG Kokott.

114 See Directive 2005/35/EC concerning ship-source pollution and on the introduction of penalties for infringements, OJ 2005 L 255/11, recitals 2, 3, 15 of the Preamble and Article 1(1).

115 See Klabbers 2012, 129-131, who puts this rationale forward as an acceptable explanation for the Court's sometimes reluctant attitude towards international law. This may be true with respect to a case like Kadi, but is harder to defend with respect to cases such as Intertanko and Air Transport Association of America.
} 


\subsubsection{EU Law v Binding International Agreements: Mox Plant and UNCLOS}

Kadi, Intertanko and Air Transport Association of America are examples of cases in which the ECJ was (partly) confronted with norms stemming from international organisations of which the EU is not a member. That these norms reached the border of the EU legal order is indicative of the fact that there is growing discontinuity between the Union's internal legislative activities and its scope of action on the external plane. All the same, the majority of external relations cases which come before the Court involve treaties to which the EU-alone or with the Member States-has committed itself (or is about to commit itself) and which thus form part of the EU legal order. Obviously, there are different dynamics at work in such cases. As will be recalled, however, this does not mean that the concept of autonomy has no role to play here.

When it comes to international norms which are intended to formally bind the EU, one can distinguish between two types of situations. First, there is the Opinion 1/91 type of situation in which the ECJ gets to decide ex ante, on the basis of what is now Article 218(11) TFEU, whether it thinks that an international treaty is compatible with EU law. Recently, in Opinion 1/09, a negative answer in this regard was given with respect to the Agreement on the European and Community Patents Court. ${ }^{116}$ In order to overcome what is now a very cumbersome and timeconsuming practice, this draft treaty created a unified patent litigation system outside the Union framework. This system would, if it had entered into force, have divested national courts of their jurisdiction to hear patents cases and of their power to refer questions to the ECJ under the preliminary reference procedure in this respect. The Court did not approve of this arrangement. National courts, it asserted, operate as "the guardians" of the EU legal order and judicial system. ${ }^{117}$ To cut them out of the equation, and replace them with an international court with jurisdiction to interpret EU law, would put the autonomy of the EU at risk. ${ }^{118}$

If anything, Opinion 1/09 shows that the ECJ's concern for jurisdictional competition-now, interestingly, expanded to national courts - is still very much alive. Or, as one commentator put it, "it has once more become clear that the European Union is a difficult partner to deal with internationally". ${ }^{119}$ Whether this concern was well founded in Opinion 1/09 from a perspective which takes the autonomy of the EU to be a boundary concept, can be debated. However, that discussion will not be

116 ECJ Opinion 1/09 Agreement on the European and Community Patents Court, judgment of 8 March 2011, not yet reported.

117 Ibid., para 66.

118 The draft treaty sought to repair this situation by placing the Patents Court under an obligation to refer questions to the ECJ instead. However, this could not convince the ECJ, that, unlike within EU law, there were no enforcement mechanisms in place in case the Patents Court would fail to fulfil this duty. Ibid., paras 86-89.

119 Lock 2011b, 588. 
pursued here. ${ }^{120}$ Instead, we will focus on the Mox Plant Decision, a case in which the issue of autonomy surfaced after the conclusion of the international agreement that formed of the subject of the proceedings.

As we saw earlier, Mox Plant concerned the question whether one Member State, Ireland, could sue another Member State, the UK, before a tribunal that had been set up under UNCLOS, a mixed treaty. ${ }^{121}$ Specifically, the case centred on Article 292 TEC (now Article 344 TFEU), which provides that Member States shall not submit a dispute concerning the interpretation or application of European law to any method of settlement outside the Treaty framework. To answer the question whether Ireland had breached this provision, the parties, predictably, focused on the issue of competence. Ireland claimed that in the specific environmental policy area under consideration the Community had only adopted minimum rules. As a result, it could not be said that the related fields of shared competence had been transferred within the framework of UNCLOS and, thus, also not that the Court had exclusive jurisdiction by virtue of Article 292 EC. ${ }^{122}$ Siding with the Commission, the ECJ rejected this argument. According to the Court, it was clear that the UNCLOS provisions on which Ireland relied came within the scope of Community competence which it had "elected to exercise by becoming a party to the Convention". ${ }^{123}$ Consequently, those provisions formed part of the EC legal order and the ECJ had jurisdiction to deal with disputes relating to their interpretation and application. ${ }^{124}$

Leaving aside whether its specific way of reasoning was convincing, it is hard to argue with the Court's conclusion in Mox Plant that the UNCLOS provisions at issue had become part of the Community's legal order and, therefore, within its jurisdiction to judge upon. As a matter of fact, the sole fact that UNCLOS had been concluded under Article 300 TEC (now Article 216 TFEU) can be said to have been sufficient for this conclusion. ${ }^{125}$ But was it subsequently also really necessary to infer from this that its jurisdiction was exclusive? The Court had few doubts on this issue. Recalling that the Community constitutes an autonomous legal order, it just declared that now that the relevant UNCLOS provisions, through their incorporation in the European legal order, had effectively become Community law, it was evident that a dispute concerning their interpretation fell within the scope of Article 292 TEC. ${ }^{126}$ If the ECJ is serious about its duty to respect international

120 The road of Article 218(11) TFEU will also no doubt be taken when the EU, in the nearby future, has a draft treaty ready for its legally prescribed accession to the European Convention on Human Rights (ECHR). Already, there are clear indications that the ECJ is anxious about the autonomy of the EU legal order in the light of this accession, especially where it concerns its own power to interpret EU law. See on this concern e.g. Lock 2011a; Jacqué 2011. Cf. further Chap. 5 of this volume.

121 ECJ Case C-459/03 Commission v Ireland (Mox Plant) [2006] ECR I-4635. See Sect. 2.2.

122 Ibid., para 102.

123 Ibid., para 120.

124 Ibid., paras 120-121.

125 See supra n. 33.

126 ECJ Case C-459/03 Commission v Ireland (Mox Plant) [2006] ECR I-4635, paras 122-127. 
law, however, then this assumption, arguably, is not self-evident. Indeed, one could also turn this argument around. That is, because UNCLOS, in contrast to for example the UN Charter or Marpol, forms a part of European law, the EU has an extra responsibility to see to it that its norms are complied with. ${ }^{127}$

Admittedly, Article 344 TFEU is clear about the fact that Member States are not supposed to settle disputes that touch upon EU law outside the Treaty framework. It is not therefore suggested that the ECJ was per se wrong when it decided in Mox Plant that Ireland had violated its obligations under European law. It could, however, have paid more attention to the question whether the infringement of the EU's unity in the present case-read: the degree of harmonisation of secondary law in the specific policy area-was really so obvious so as to justify, under a "liberal" reading of the concept of autonomy, that the arbitration mechanism of UNCLOS was shut out. Had it done so, the Court would have contributed to a better understanding of when exactly "the ordre public as the boundary of commitment under treaty" comes into sight for the EU.

In this respect, it is interesting to note that Ireland, by way of an alternative submission, contended that if the Court were to conclude that the provisions of UNCLOS invoked before the Arbitral Tribunal formed an integral part of Community law, that conclusion would also be unavoidable with regard to the provisions of UNCLOS dealing with dispute settlement. The initiation of proceedings before the Tribunal by Ireland against the UK, therefore, constituted "a method of dispute settlement provided for in the EC Treaty, within the terms of Article 292 EC". The ECJ rejected this argument. In doing so, it not only relied on the autonomy of EU law, but also on Article 282 UNCLOS, which provides that if parties to UNCLOS "are parties to a dispute concerning the interpretation or application of this Convention have agreed (...) that such dispute shall (...) be submitted to a procedure that entails a binding decision, that procedure shall apply..." 128 It is not certain, however, whether Article 282 UNCLOS was really designed to apply to the procedure of Article 344 TFEU. ${ }^{129}$ In a similar vein, one may also point to Article 4(6) Annex IX UNCLOS, which provides that in "the event of a conflict between the obligations of an international organisation under this Convention and its obligations under the agreement establishing the organisation or any acts relating to it, the obligations under this Convention shall prevail." While there may not have been an actual material conflict between European law and UNCLOS in Mox Plant, this clause, which is similar to Article 103 UN, could, as an integral part of the EU legal order, nonetheless have persuaded the ECJ to set aside its concerns for the unity of the EU legal order in the present case.

127 Here, again, one may point to the Court's own Kupferberg rationale, which holds that by incorporating international norms within its legal order, the Union intends to show third parties that it is a reliable international partner. See ECJ Case 104/81 Kupferberg [1982] ECR 3641.

128 ECJ Case C-459/03 Commission v Ireland (Mox Plant) [2006] ECR I-4635, paras 130-133.

129 See Schrijver 2010, 874-875. 


\subsection{Conclusion}

In this chapter, it was submitted that the concept of the autonomy of the EU legal order in fact constitutes a disguised claim to sovereignty. That in itself already tells us that one of the questions underpinning the central issue of this study-whether the EU can still be seen as an autonomous legal order-should receive an affirmative answer. For sovereignty is not something that slowly fades away as an entity becomes more dependent on the influence of international law. On the contrary, being a normative claim to authority closely intertwined with international law, it is an essential device in structuring and ordering this legal category. Accordingly, the real question is not if the Union is still autonomous, but how it imposes its autonomy on the international legal order, in particular on normative decisions or founding documents of (other) international organisations.

Looking to the ECJ's case law on the interaction between EU law and international law, conceptually speaking, it does not make any difference if an international norm that arrives at the border of the EU legal order is generated by an international organisation or belongs to a more general body of public international law. In order to make any real impact in the EU legal order, in principle all international norms will, regardless of their origins, have to comply with a twopronged test: that is, (1) they have to be binding on the EU, and (2) the nature and the broad logic of these norms should not preclude this. At the same time, in a factual way it is clear that norms which derive from international organisations are likely to have a greater impact than, say, customary international law, which, normally, will be harder to pin down. All the more so, since the world, over the past decades, has grown into a place in which cooperation through multilateral forums has become the standard and in which international organisations are rife.

The phenomenon of globalisation, of which the EU is itself an early expression, did not escape the attention of the framers in what eventually, in December 2009, entered into force as the Treaty of Lisbon. Article $21 \mathrm{TEU}$, besides vowing to respect international law in a general sense, explicitly spurs the Union to develop relations with regional and global organisations and, in this respect, specifically mentions the UN framework. It will be interesting to see how the ECJ responds to these changes. As was discussed in the final section of this chapter, in the recent past the Court has sometimes struggled with finding a proper balance between openness towards international law and defending the integrity of its own legal order. In part, this can be ascribed to some specific constitutional problems which the EU faces, in particular due to a growing discontinuity between its internal legislative activities and its scope of action on the external plane. It is clear that the Court is not solely responsible for solving these problems. Furthermore, in the spirit of Article 4(3) TEU, there are already several mechanisms in place which aim to safeguard the unity of the EU, deal with the fact that, despite having competence in this regard, the EU is not always capable to act on the international plane, and coordinate at the internal level how external action that affects EU law 
should take place. ${ }^{130}$ Occasionally, nonetheless, the ECJ could try to be more forthcoming towards international law.

As recent decisions show, this is especially the case when the Court acts out of concern for the unity of the internal market, which can either manifest itself when it refuses to take into account international agreements which are not formally binding upon the EU (Intertanko and Air Transport Association of America) or alternatively when the exclusive character of the EU's judicial system is allegedly put at risk (Mox Plant and Opinion 1/09). The reason why it might make sense to change course in situations like these in the future, it was submitted in this chapter, is that the ECJ's attitude towards international law in such cases somewhat contrasts with the EU's constitutional cloak. When the Court protects the EU from the normative impact of international law, it does so out of a (spoken or unspoken) concern for the autonomy of the EU, the founding stone of its gradual constitutionalisation. However, while it may be true that this constitutionalisation would never have come about without a firm insistence on the unity of EU law, one could argue that today this rather forms an impediment in this respect. ${ }^{131}$ In other words, if the ECJ is serious about its claim that the Union constitutes an entity with distinct constitutional features, it should be prepared to translate this into a policy of deference towards external norms; something which, as was suggested, is only to be reversed when the identity of the EU is at stake. Under a modern, liberal reading of the concept, more autonomy vis-à-vis international law in effect might mean less autonomy.

\section{References}

Avbelj M (2008) Questioning EU constitutionalisms. German Law J 9:1-26

Baquero Cruz J (2008) The legacy of the Maastricht-Urteil and the pluralist movement. Eur Law Rev 14:389-422

Barents R (2004) The autonomy of community law. Kluwer Law International, The Hague

Barents R (2009) The precedence of EU law from the perspective of constitutional pluralism. Eur Const Law Rev 5(3):421-446

130 See Cremona 2011, 253-260. Cf. also Hillion 2010.

131 There are interesting parallels here with the EU's inner functioning. Think e.g. of the practice with respect to the preliminary reference procedure. Fifty years after Van Gend, in which it transformed this procedure into the catalyst of the integration process, the Court still holds on to a fairly strict interpretation as to how national courts should function in the framework created by this. The uniform application of EU law by national courts is still at the top of its list in this regard. (Cf. to this end e.g. ECJ Case C-366/10 The Air Transport Association of America and Others, judgment of 21 December 2011, not yet reported, paras 46-47). Over the past couple of years, however, commentators and judges have put forward several interesting suggestions to tone this practice down. The common denominator behind these suggestions: the EU has grown into a relatively mature constitutional being, and does not need its fixation on unity anymore. See e.g. AG Cruz Villalón's Opinion to ECJ Case C-173/09 Elchinov, judgment of 5 October 2010, not yet reported. Further cf. Komárek 2007. 
Besselink L (2007) Een samengestelde Europese constitutie/a composite European constitution. Europa Law Publishing, Groningen

Bieber R (2009) Comments on the German constitutional court's decision on the Lisbon Treaty: 'an association of states'. Eur Const Law Rev 5:391-406

Böckenförde EW (1991) Staat, verfassung, demokratie. Suhrkamp, Frankfurt am Main

Castillo de la Torre F (2002) Opinion 1/00 proposed agreement on the establishment of a European aviation area, 18 April 2002, not yet reported, 39. Common Mark Law Rev 39:1373-1393

Craig P, De Búrca G (2008) EU law: text, cases, and materials. Oxford University Press, Oxford

Cremona M (2011) External relations and external competence of the European Union: the emergence of an integrated policy. In: Craig P, De Búrca G (eds) The evolution of EU law. Oxford University Press, Oxford. pp 217-268

De Búrca G (2010) The European Court of Justice and the international legal order after Kadi. Harv Int Law J 51:1-49

De Witte B (1998) Sovereignty and European integration: the weight of legal tradition. In: Slaughter AM et al (eds) The European court and national courts-doctrine and jurisprudence: legal change in its social context. Hart Publishing, Oxford, pp 277-304

De Witte B (2010) European Union law: How autonomous is its legal order? Zeitschrift für Öffentliches Recht 65:141-155

De Witte B (2011) Direct effect, primacy, and the nature of the legal order. In: Craig P, De Búrca G (eds) The evolution of EU law. Oxford University Press, Oxford, pp 323-362

Dekker I, Wessel R (2010) De aangesproken lidstaat: De internationale aansprakelijkheid en verantwoordelijkheid van de staat als lid van een internationale organisatie. In: Besselink LFM, Nehmelman R (eds) De aangesproken staat: Verantwoordelijkheid, aansprakelijkheid en ommuniteit van de overheid. WLP, Nijmegen, pp 157-183

Eckes (2010) Case C-188/07 Commune de Mesquer v Total France and Total International Ltd., Judgment of the Court (Grand Chamber) of 24 June 2008 [2008] ECR I-4501; Case C-301/08 Irène Bogiatzi v Deutscher Luftpool, Société Luxair, European Communities, Luxembourg, Foyer Assurances SA, Judgment of the Court (Fourth Chamber) of 22 October 2009, nyr. Common Mark Law Rev 47:899-915

Eckes C (2012a) International law as law of the EU: The role of the European Court of Justice. In: Cannizzaro et al. (eds) International law as law of the European Union. Martinus Nijhoff Publishers, Leiden and Boston, pp 353-378

Eckes C (2012b) Protecting supremacy from external influences: a precondition for a European constitutional legal order? Eur Law J 18(2):230-250

Editorial Comments (2011) The Union, the Member States and international agreements. Common Mark Law Rev 48:1-7

Eeckhout P (2004) External relations of the European Union: legal and constitutional foundations. Oxford University Press, Oxford

Eeckhout P (2009) Case C-308/06 The Queen on the application of Intertanko and others v Secretary of State for Transport, judgment of the Court of Justice (Grand Chamber) of 3 June 2008, not yet reported. Common Mar Law Rev 46:2041-2057

Eeckhout P (2010) Bold constitutionalism and beyond. In: Poiares Maduro M, Azoulai L (eds) The past and future of EU law: the classics of EU law revisited on the 50th anniversary of the Rome Treaty. Hart Publishing, Oxford and Portland, pp 218-223

Gattini A (2009) Joined Cases C-402/05 P \& C-415/05 P Yassin Kadi and Al Barakaat International Foundation v Council and Commission, judgment of the Grand Chamber of 3 September 2008, nyr. Common Mark Law Rev 46:213-239

Govaere I (2010) Beware of the Trojan horse: Dispute settlement in (mixed) agreements and the autonomy of the EU legal order. In: Hillion C, Koutrakos P (eds) Mixed agreements revisited: the EU and its Member States in the world. Hart Publishing, Oxford and Portland, pp 187-207

Grabenwarter C (2010) National constitutional law relating to the European Union. In: Von Bogdandy A, Bast J (eds) Principles of European constitutional law, Hart Publishing and Verlag CH Beck, Oxford and München, pp 83-129 
Griller S (2008) International law, human rights and the European Community's autonomous legal order: notes on the European Court of Justice decision in Kadi. Eur Const Law Rev 4:528-553

Halberstam D, Stein E (2009) The United Nations, the European Union, and the King of Sweden: economic sanctions and individual rights in a plural world order. Common Mark Law Rev 46:13-72

Hartley T (2001) The constitutional foundations of the European Union. Law Q Rev 117:225-246

Hillion C (2010) Mixity and coherence: The significance of the duty of cooperation. In: Hillion C, Koutrakos P (eds) Mixed agreements revisited: the EU and its Member States in the world. Hart Publishing, Oxford and Portland, pp 87-115

Hoffmeister F (2010) Curse or blessing? Mixed agreements in the recent practice of the European Union and its Member States. In: Hillion C, Koutrakos P (eds) Mixed agreements revisited: the EU and its Member States in the world. Hart Publishing, Oxford and Portland, pp 249-268

Heller H (2002) The essence and structure of the state. In: Jacobson AJ, Schlink B (eds) Weimar: a jurisprudence of crisis, University of California Press, Berkely, Los Angeles and London, pp 265-279

Hoeksma J (2011) The EU as a democratic polity in onternational law, CLEER Working Papers $2011 / 2$

Holdgaard R (2008) External relations law of the European Community: legal reasoning and legal discourses. Wolters Kluwer, Alphen aan de Rijn

Jacque $J$ (2011) The accession of the European Union to the European convention on human rights and fundamental freedoms. Common Mar Law Rev 48:995-1024

Kelsen H (2007) General theory of law and state. Transaction Publishers, New Brunswick

Klabbers J (2009) Treaty conflict and the European Union. Cambridge University Press, Cambridge

Klabbers J (2012) The validity of EU norms conflicting with international obligations. In: Cannizzaro E et al (eds) International law as law of the European Union. Martinus Nijhoff Publishers, Leiden and Boston, pp 111-132

Komárek J (2007) In the court(s) we trust? On the need for hierarchy and differentiation in the preliminary ruling procedure. Eur Law Rev 32(4):467-491

Komárek J (2009) The Czech Constitutional Court's second decision on the Lisbon Treaty of 3 November 2009: excerpts from a translation. Eur Const Law Rev 5:345-352

Koskenniemi M (1989) From apology to utopia: the structure of international legal argument. Finnish Lawyers' Pub. Co., Helsinki

Koutrakos P (2006) EU international relations law. Hart Publishing, Oxford and Portland

Lavranos N (2010) Protecting European law from international law. European Foreign Aff Review 15:265-282

Lenaerts K, Van Nuffel P (2005) Constitutional law of the European Union. Sweet \& Maxwell, London

Lindahl H (2003) Sovereignty and representation in the European Union. In: Walker N (ed) Sovereignty in transition. Hart Publishing, Oxford and Portland, 87-114

Lindahl H (2007) Constituent power and reflexive identity: towards an ontology of collective selfhood. In: Loughlin M, Walker N (eds) The paradox of constitutionalism: constituent power and constitutional form. Oxford University Press, Oxford, pp 9-24

Lock T (2011a) Walking on a tightrope: The draft ECHR accession agreement and the autonomy of the EU legal order. Common Mark Law Rev 48:1025-1054

Lock T (2011b) Taking national courts more seriously? Comment on Opinion 1/09. Eur Law Rev 36:576-588

MacCormick N (1995) The Maastricht-Urteil: sovereignty now. Eur Law J 1:259-266

Mayer F (2010) Multilevel constitutional jurisdiction. In: Von Bogdandy A, Bast J (eds) Principles of European constitutional law. Hart Publishing and Verlag CH Beck, Oxford and München, pp 399-439

Meij A (2010) Circles of coherence: on unity of case-law in the context of globalisation. Eur Const Law Rev 6:84-101 
Mendez M (2010) The enforcement of EU agreements: bolstering the effectiveness of treaty law? Common Mark Law Rev 47:1719-1756

Oeter S (2010) Federalism and democracy. In: Von Bogdandy A , Bast J (eds) Principles of European constitutional law. Hart Publishing and Verlag CH Beck, Oxford and München, pp 55-82

Pernice I (2009) The Treaty of Lisbon: multilevel constitutionalism in action. Columbia J Eur Law 15:349-407

Pernice I (2011) Der Schutz nationaler Identität in der Europäischer Union. Archiv des öffentlichen Rechts 136(2):185-221

Peters A (1997) The position of international law within the European Community legal order. Ger Yearb Int Law 40:9-77

Peters A (2009) Humanity as the A and $\Omega$ of sovereignty. Eur J Int Law 20:513-544

Peters A (2010) Rechtsordnungen und Konstitutionalisierung: Zur Neubestimmung der Verhältnisse. Zeitschrift für Öffentliches Recht 65:3-63

Poiares Maduro M (2005) The importance of being called a constitution: constitutional authority and the authority of constitutionalism. Int J Const Law 3:332-356

Poiares Maduro M, Azoulai L (eds) (2010) The past and future of EU law: the classics of EU law revisited on the 50th anniversary of the Rome Treaty. Hart Publishing, Oxford and Portland

Richmond C (1997) Preserving the identity crisis: autonomy, system and sovereignty in European law. Law Philos 16:377-420

Schiemann K (2007) Europe and the loss of sovereignty. Int Const Law Q 56:475-490

Schilling T (1996) The autonomy of the community legal order-an analysis of possible foundations. Harv Int Law J 37:389-409

Schmitt C (2003) Verfassungslehre. Duncker \& Humblot, Berlin

Schrijver N (2010) Case C-459/03 Commission of the European Communities v Ireland, Judgment of the Court (Grand Chamber) of 30 May 2006, [2006] ECR I-4653. Common Mark Law Rev 47:863-878

Schütze R (2006-2007) EC law and international agreements of the Member States-an ambivalent relationship? Camb Yearb Eur Legal Stud 9:387-440

Schütze R (2009) From dual to cooperative federalism: the changing structure of European law. Oxford University Press, Oxford

Sillen J (2010) Rechtsgevolgen van toetsing van wetgeving, dissertation. Radboud University, Nijmegen

Simma B, Pulkowski D (2006) Of planets and the universe: self-contained regimes in international law. Eur J Int Law 17:483-529

Storost U (2000) “...dem Frieden der Welt zu dienen”: Gedanken zur Zukunft der Staatlichkeit. In: Murswiek et al. (eds) Staat - Souveränität - Verfassung: Festschrift für Helmut Quaritsch zum 70. Geburtstag, Duncker \& Humblot, Berlin, pp 31-44

Thym D (2009) In the name of sovereign statehood: a critical introduction to the Lisbon judgment of the German Constitutional Court. Common Mark Law Rev 46:1795-1822

Tietje C (2008) The status of international law in the European legal order: The case of international treaties and non-binding international instruments. In: Wouters $\mathbf{J}$ et al (eds) The Europeanisation of international law: the status of international law in the EU and its Member States. T.M.C. Asser Press, The Hague, pp 55-69

Tomuschat C (2010) Lisbon-terminal of the European integration process? The judgment of the German Constitutional Court of 30 June 2009. ZaöRV 70:251-282

Uerpmann-Wittzack R (2010) The constitutional role of international law. In: Von Bogdandy A, Bast J (eds) Principles of European constitutional law. Hart Publishing and Verlag CH Beck, Oxford and München, pp 131-167

Van Rossem J (2009) Interaction between EU law and international law in the light of Intertanko and Kadi: the dilemma of norms binding the member states but not the Community. Neth Yearb Int Law 40:183-227 
Van Rossem J (2012) The EU at crossroads: a constitutional inquiry into the way international law is received within the EU legal order. In: Cannizzaro E et al (eds) International law as law of the European Union. Martinus Nijhoff Publishers, Leiden and Boston, pp 59-89

Vauchez A (2010) The transnational politics of judicialization: Van Gend en Loos and the making of EU polity. Eur Law J 16:1-28

Von Bogdandy A (2010) Founding principles. In: Von Bogdandy A, Bast J (eds) Principles of European constitutional law. Hart Publishing and Verlag $\mathrm{CH}$ Beck, Oxford and München, pp 11-54

Von Bogdandy A, Schill S (2011) Overcoming absolute primacy: respect for national identity under the Lisbon Treaty. Common Mark Law Rev 48:1417-1454

Vo $\beta$ kuhle A (2010) Multilevel cooperation of the European constitutional courts: Der Europäische Verfassungsgerichtsverbund. Eur Const Rev 6:175-198

Walker N (2002) The idea of constitutional pluralism. Mod Law Rev 65:317-359

Walker N (ed) (2003a) Sovereignty in transition. Hart Publishing, Oxford and Portland

Walker N (2003b) Late sovereignty in the European Union. In: Walker N (ed) Sovereignty in transition. Hart Publishing, Oxford and Portland, pp 3-32

Weiler J (1991) The transformation of Europe. Yale Law J 100:2403-2483

Weiler J, Haltern U (1996) The autonomy of the Community legal order: through the looking glass. Harv Int Law J 37:411-448

Werner W (2004) State sovereignty and international legal discourse. In: Dekker IF, Werner W (eds) Governance and international legal theory. Martinus Nijhoff Publishers, Leiden and Boston, pp 125-157

Ziegler K (2009) Strengthening the rule of law, but fragmenting international law: the Kadi decision of the ECJ from the perspective of human rights. Hum Rights Law Rev 9:288-305 


\section{严 Springer}

http://www.springer.com/978-90-6704-902-3

Between Autonomy and Dependence

The EU Legal Order under the Influence of International

Organisations

(Eds.)R.A. Wessel; S. Blockmans

2013, VIII, 340 p., Hardcover

ISBN: $978-90-6704-902-3$ 